\title{
Property Crime and Socioeconomic Factors
}

\author{
Shijie Yin \\ Economic Department, Missouri State University, Springfield, USA \\ Email: ysh94545@live.missouristate.edu
}

How to cite this paper: Yin, S.J. (2017) Property Crime and Socioeconomic Factors. Open Journal of Social Sciences, 5, 226-237.

https://doi.org/10.4236/jss.2017.59016

Received: August 6, 2017

Accepted: September 22, 2017

Published: September 25, 2017

Copyright $\odot 2017$ by author and Scientific Research Publishing Inc. This work is licensed under the Creative Commons Attribution International License (CC BY 4.0).

http://creativecommons.org/licenses/by/4.0/ (c) (i) Open Access

\begin{abstract}
This paper analyzes the relationship between property crime and socioeconomic factors by choosing section data of American states from 2011 to 2015. The research shows that: 1) The factors-unemployment rate, median household income and education level do not strong affect the change of property crime; the covered people of unemployment insurance policy and law enforcement are significant for variance to property crime. 2) Economic determinants should be included in the model of criminal activity, but the economic model does not explain the overall change in crime rates.
\end{abstract}

\section{Keywords}

Property Crime, Unemployment Rate, Median Household Income,

Unemployment Insurance Policy, Educational Condition, Cross-Sectional Data

\section{Introduction}

In this paper, we analyze the relationship between property crime and socioeconomic factors. Our data is cross-sectional data. Our model and outcomes of property crime and five socioeconomic explanatory variables predict that: 1) neither economic nor non-economic factors appear to be more important in influencing property crime rates. 2) Law enforcement has strong negative relationship with property crime. 3) The covered number of employees by unemployment insurance policy has strong positive relationship with property crime. The empirical analysis using cross-sectional data from Bureau of Labor Statistics and uniform crime reporting of Federal Bureau of Investigation (FBI) provide empirical support to these predictions.

It is not doubt that property crime is a serious social problem in United State. According to the uniform crime reporting of FBI, in 2015, there were an estimated 7,993,631-property crime's offenses in the nation, which resulted in losses estimated at $\$ 14.3$ billion in 2015 (FBI: UCR, 2015) [1]. More seriously, only 
about half of the violent crimes and a third of the property crimes that occurred in the United States each year reported to police. Moreover, most of the reported crimes did not result in the arrest, charging and prosecution of a suspect, according to government statistics (John Gramlich, 2017) [2].

Therefore, what is the professional definition of property crime? According to the introduction of FindLaw, property crime is a category of crime that includes the offenses of burglary, larceny-theft, motor vehicle theft, and arson. It is a crime to obtain money, property, or some other benefit. This may involve force, or the threat of force, in cases like robbery or extortion (FindLaw, 2017) [3]. Beyond questions, property crime has correlation with socioeconomic factors. The socioeconomic factors or status defined as the social standing or class of an individual or group (American Psychological Association, 2017) [4]. Socioeconomic status (SES) usually measured by determining education, income, occupation, or a composite of these dimensions (Winkleby, Jatulis, Frank, and Fortmann, 1992) [5]. According to definition of socioeconomic factors or status, education, income, policy and unemployment rate are some typical socioeconomic factors.

Do higher economic condition and a good social environment help to decrease the property crime? Empirically, better economic condition means less incentive to theft. However, without looking in further details-what drives property crime and how the determinants of socioeconomic factors affect property crime, we cannot arbitrary make conclusion. As a result, this paper attempts to analyze the relationship between the property crime and socioeconomic factors.

More specifically, this paper empirically investigates the importance of gun law, unemployment rate, median household income, unemployment insurance policy and educational condition in explaining the change of property crime.

\section{Economic Theory}

In this section, we offer a regression model to demonstrate the relationship between the property crime and socioeconomic factors.

$$
C=\beta_{0}-\beta_{1} L+\beta_{2} U R-\beta_{3} I-\beta_{4} U I-\beta_{5} E+\varepsilon
$$

Firstly, we predicted that the law enforcement for an explanatory variable. In this model, " $L$ " uses to present law enforcement or gun law. The reason added this explanatory variable is that, from underlying theories, the law enforcement has strong relationship with the successful possibility of property crime-specially the gun law. Since empirically, if the criminals take the gun and rob, they have more threaten for victims and more likely to success. As a result, the dummy variable-gun law added in the model. We estimate that gun law has two side impacts (positive or negative) on property crime, since gun can use to help the criminals and can act as a deterrent for victims.

Secondly, we predicted that the unemployment rate for an explanatory variable. In this model, "UR" uses to present the unemployment rate. The reason 
added this variable is that the opportunity cost of being imprison for a criminal relates to the job time and wage if the criminal. As a result, the lower the unemployment rate the higher the cost of a given prison sentence to an individual; therefore, a positive coefficient is anticipated (Roy M. Howsen and Stephen B. Jarrell, 1987) [6].

Thirdly, we predicted that the median household income for an explanatory variable. In this model, " $P$ " uses to present the median household income. In similar circumstances, the people with desirable wages are less likely to steal. The combination of poverty with opportunity leads to property crime (John Gramlich, 2017) [2]. We estimate that high income will cause less property crime since more income will decrease the incentive of property crime.

Fourthly, we predicted that the number of employee covered by unemployment insurance policy for an explanatory variable. In this model, "UP' uses to present the number of employee covered by unemployment insurance policy. Because people who covered by unemployment insurance policy will be less anxious for poverty when they loss their job. Therefore, we estimate that more people covered by unemployment insurance policy will cause less property crime since unemployment policy will decrease the incentive of property crime.

Fifthly, we predicted that the education level for an explanatory variable. In this model, " $E$ " uses to present the education level. Because the education can foster the rule of law and have more intelligent and social consideration about the property crime. The data of high school graduate percentage rate uses in the model since high school degree is enough to develop a mindset of acting within law. We estimate that high percentage of high school graduate will cause less property crime since more percentage of high school graduate will decrease the incentive of property crime.

\section{Empirical Analysis}

\subsection{Data}

In this model, the data of dependent variable "Property Crime" collected from the Uniform Crime Reporting of Federal Bureau of Investigation (FBI). The data based on actually reported property crime. The units of measurement of property crime are by volume and rate per 100,000 inhabitants, in years, in state i, 2014. The data of "Gun Law" collected from PubMed Central. The data is a dummy variable, which is if it equal to 1 if state $i$ had a strict and implemented firearm law to control the use of gun, 0 otherwise, 2010. The data of "Unemployment Rate" collected from Bureau of Labor Statistics. The units of measurement of unemployment rate are by percentage of unemployment rate for state i, annual averages, 2014. The data of "Median Household Income" collected from Wikipedia. The units of measurement of median household income is average household income of city's citizen per dollar, in years, in state i, 2014. The data of "Unemployment Insurance Policy" collected from United States Department of Labor. The data produced from state-reported data. In this paper, 
the data of $4^{\text {th }}$ quarter of 2014 used. There are many index to use in this Labor Force Information website. The covered insured unemployment insurance case of regular programs should use since it is more fitted for this model. The covered unemployment insurance case can show how many people covered by unemployment insurance policy so that it has more strong relationship with the possibility of poverty and more affect the incentive of property crime. The unit of measurement of unemployment insurance policy is level in thousands of people, in state i, 2014. Finally, the data of "Education Level" collected from Governing Magazine. The unit of measurement of education level is the percentage of high school graduate in state i, based 5-year estimates (2011-2015).

\subsection{Estimation Framework}

Based on the Eviews outcome (which is in Appendix Table 1), the regression function is specific as follows:

$$
\begin{aligned}
& C=14585.41-7057.754 L-507.8496 U R+0.02192 I-88.7303 U I-921.9806 E \\
& -1.92
\end{aligned}
$$

Adjusted R-squared $=0.1174 . \mathrm{N}=51$ (Sample based on year of 2014)

We try to use the right-log form for the variable "Unemployment Rate" and "Education Level" since both two are percentage change for independent variable. However, from printout of Eviews (which is in Appendix Table 2), the change of form does not improve the model much. It does decrease the standard error of "Law Enforcement" and slight improve adjusted R-squared. However, it strong increases the standard error of two variables "Unemployment Rate" and "Education Level". As a result, we reject the right-log model.

From the outcome of Eviews, we find that the adjusted R-squared is very small. On the other hand, the standard error is great for variables "Law Enforcement", "Unemployment Rate", "Unemployment Insurance Policy" and "Education Level". The sign of coefficient about variables "Law Enforcement", "Unemployment Rate", "Median Household Income" and "Unemployment Insurance Policy" are very different with what we predicted. The P value of variables "Unemployment Rate", "Median Household Income", and "Education Level" are great so that they are not significant at 0.1 level. Since the most of variables' standard error are huge so that the confidence intervals also are broad. In conclusion, the overall goodness of fit is not good. As a result, from our sample and model, neither economic nor non-economic factors appear to be more important in influencing property crime rates.

We also run a Ramsey RESET Test using Eviews (which is in Appendix Table 3 ), the number of fitted term is 2 . From the Ramsey RESET Test, the P value is 0.0047 , under 0.1 significant lever, we cannot reject null hypothesis, and as a result, there are some problems of omitted variable in the model.

To test the problem of multicollinearity, we also use the coefficient covariance (which is in Appendix Table 4) and variance inflation factor (VIF) (which is in 
Appendix Table 5), according the Eviews, none of variable's coefficient covariance is greater than 0.8 ; meanwhile, there are no one of variance inflation factor greater than 5 . As a result, we conclude that there is no problem of multicollinearity in the model.

Finally, we do the residual graph (Appendix Figure 1), B-P test (Appendix Table 6) and white test (Appendix Table 7) to check the possibility of getting problem of heteroscedasticity. From the residual graph, the variable "Unemployment Insurance Policy" may has the problem of heteroscedasticity since the residual graph like a corn shape. From the outcome of $\mathrm{B}-\mathrm{P}$ test, the $\mathrm{P}$-value is 0.3134 , which is insignificant at 0.1 level. Furthermore, from the outcome of White test, the $\mathrm{P}$ value is 0.1779 that also is insignificant at 0.1 level. As a result, we conclude that there are some problems of heteroscedasticity in the model. For the remedies, we suggest to use the Heteroscedasticity-Corrected Standard Error (Appendix Table 8). Finally, we choose the Heteroscedasticity-Corrected Standard Error and do not change other data.

\section{Concluding Remarks}

In this paper, we analyze the relationship between property crime and socioeconomic factors, using cross-section data of each state in U.S.A. We built a regression model using the explanatory variables "Law Enforcement", "Unemployment Rate", "Unemployment Insurance Policy", "Median Household Income" and "Education Level" to explain the "Property Crime".

Our main empirical findings based on the Eviews are out of our expectation. Interestingly, from our sample and model, neither economic nor non-economic factors appear to be more important in influencing property crime rates. The factors-unemployment rate, median household income and Education Level do not strongly affect the change of property crime. The covered people of unemployment insurance policy and law enforcement are significant for effect to property crime. There is a significant outcome relating with the variables "covered number of employees by unemployment insurance". From the actual outcome of regression model using Eviews (Appendix Table 8), the coefficient of variable "covered number of employees by unemployment insurance" is 88.73031. It means that, holding other variables constant, if the number of employee covered by unemployment insurance policy increases 1000, approximately, the dependent variable "property crime" will increase 89 cases.

In conclusion, the results suggest that, even though economic determinants are important and should be included in models of criminal activity, an economic model does not account for the total variation in crime rates. Other disciplinary theories or a synthesis of these theories may reduce the unexplained variation (Roy M. Howsen and Stephen B. Jarrell, 1987) [6].

\section{References}

[1] FBI: Uniform Crime Reporting, April 07, 2015. 
https://ucr.fbi.gov/crime-in-the-u.s/2015/crime-in-the-u.s.-2015/offenses-known-to -law-enforcement/property-crime

[2] John, G. (2017) Most Violent and Property Crimes in the U.S. Go Unsolved. Pewresearch.org, March 1, 2017.

[3] Property Crimes-FindLaw. N.p., n.d. Web. 2 Sept. 2017.

http://criminal.findlaw.com/criminal-charges/property-crimes.html

[4] Socioeconomic Status. http://www.apa.org

[5] Winkleby, M.A., EJatulis, D., Frank, E. and Fortmann, S.P. (1992) Socioeconomic Status and Health: How Education, Income, and Occupation Contribute to Risk Factors for Cardiovascular Disease. American Journal of Public Health, 82, 816-820.

[6] Howsen, R.M. and Stephen, B. (1987) Economic Factors Influence Criminal Behavior but Cannot Completely Explain the Syndrome. American Journal of Economics and Sociology, Inc, May 04, 2017. http://www.jstor.org/stable/3486660 


\section{Appendix}

Table 1. The actual outcome of regression model using Eviews.

\begin{tabular}{|c|c|c|c|c|}
\hline \multicolumn{5}{|c|}{ Dependent Variable: CRIME } \\
\hline \multicolumn{5}{|l|}{ Method: Least Squares } \\
\hline \multicolumn{5}{|c|}{ Date: 05/08/17 Time: $20: 35$} \\
\hline \multicolumn{5}{|l|}{ Sample: 151} \\
\hline \multicolumn{5}{|l|}{ Included observations: 51} \\
\hline Variable & Coefficient & Std. Error & t-Statistic & Prob. \\
\hline $\mathrm{L}$ & -7057.754 & 3679.431 & -1.918164 & 0.0614 \\
\hline UR & -507.8496 & 1303.007 & -0.389752 & 0.6986 \\
\hline I & 0.021916 & 0.202546 & 0.108203 & 0.9143 \\
\hline UI & 88.73031 & 28.25142 & 3.140738 & 0.0030 \\
\hline $\mathrm{E}$ & -921.9806 & 1074.590 & -0.857984 & 0.3954 \\
\hline $\mathrm{C}$ & 14585.41 & 14111.96 & 1.033550 & 0.3069 \\
\hline R-squared & 0.205683 & \multicolumn{2}{|c|}{ Mean dependent var } & $11,664.49$ \\
\hline Adjusted R-squared & 0.117426 & \multicolumn{2}{|c|}{ S.D. dependent var } & $11,115.88$ \\
\hline S.E. of regression & 10442.86 & \multicolumn{2}{|c|}{ Akaike info criterion } & 21.45536 \\
\hline Sum squared resid & $4.91 \mathrm{E}+09$ & \multicolumn{2}{|c|}{ Schwarz criterion } & 21.68263 \\
\hline Log likelihood & -541.1116 & \multicolumn{2}{|c|}{ Hannan-Quinn criter. } & 21.54220 \\
\hline F-statistic & 2.330489 & \multicolumn{2}{|c|}{ Durbin-Watson stat } & 1.350088 \\
\hline Prob (F-statistic) & 0.057736 & & & \\
\hline
\end{tabular}

Table 2. The outcome of right-log model using Eviews.

\begin{tabular}{|c|c|c|c|c|}
\hline \multicolumn{5}{|c|}{ Dependent Variable: CRIME } \\
\hline \multicolumn{5}{|l|}{ Method: Least Squares } \\
\hline \multicolumn{5}{|c|}{ Date: 05/08/17 Time: $21: 44$} \\
\hline \multicolumn{5}{|l|}{ Sample: 151} \\
\hline \multicolumn{5}{|l|}{ Included observations: 50} \\
\hline Variable & Coefficient & Std. Error & $\mathrm{t}$-Statistic & Prob. \\
\hline $\mathrm{L}$ & -7555.853 & 3734.381 & -2.023321 & 0.0491 \\
\hline UR & -1032.405 & 15385.32 & -0.067103 & 0.9468 \\
\hline I & 0.004221 & 0.205434 & 0.020549 & 0.9837 \\
\hline UI & 89.39729 & 28.27261 & 3.161975 & 0.0028 \\
\hline $\mathrm{E}$ & -1184.301 & 2769.083 & -0.427687 & 0.6710 \\
\hline $\mathrm{C}$ & 11989.11 & 16965.49 & 0.706676 & 0.4835 \\
\hline R-squared & 0.215943 & \multicolumn{2}{|c|}{ Mean dependent var } & $11,580.10$ \\
\hline Adjusted R-squared & 0.126846 & \multicolumn{2}{|c|}{ S.D. dependent var } & $11,212.22$ \\
\hline S.E. of regression & 10477.00 & \multicolumn{2}{|c|}{ Akaike info criterion } & 21.46392 \\
\hline Sum squared resid & $4.83 \mathrm{E}+09$ & \multicolumn{2}{|c|}{ Schwarz criterion } & 21.69336 \\
\hline Log likelihood & -530.5980 & \multicolumn{2}{|c|}{ Hannan-Quinn criter. } & 21.55129 \\
\hline F-statistic & 2.423679 & \multicolumn{2}{|c|}{ Durbin-Watson stat } & 1.320806 \\
\hline Prob (F-statistic) & 0.050263 & & & \\
\hline
\end{tabular}


Table 3. Ramsey RESET test.

\begin{tabular}{|c|c|c|c|}
\hline \multicolumn{4}{|l|}{ Ramsey RESET Test } \\
\hline \multicolumn{4}{|l|}{ Equation: UNTITLED } \\
\hline \multicolumn{4}{|c|}{ Specification: CRIME L UR UI I E C } \\
\hline \multicolumn{4}{|c|}{ Omitted Variables: Powers of fitted values from 2 to 3} \\
\hline & Value & df & Probability \\
\hline F-statistic & 6.083124 & $(2,43)$ & 0.0047 \\
\hline Likelihood ratio & 12.70671 & 2 & 0.0017 \\
\hline \multicolumn{4}{|c|}{ F-test summary: } \\
\hline & Sum of Sq. & df & Mean Squares \\
\hline Test SSR & $1.08 \mathrm{E}+09$ & 2 & $5.41 \mathrm{E}+08$ \\
\hline Restricted SSR & $4.91 \mathrm{E}+09$ & 45 & $1.09 \mathrm{E}+08$ \\
\hline Unrestricted SSR & $3.83 \mathrm{E}+09$ & 43 & 88956634 \\
\hline \multicolumn{4}{|c|}{ LR test summary: } \\
\hline & Value & $\mathrm{df}$ & \\
\hline Restricted LogL & -541.1116 & 45 & \\
\hline Unrestricted LogL & -534.7582 & 43 & \\
\hline
\end{tabular}

Unrestricted Test Equation:

Dependent Variable: CRIME

Method: Least Squares

Date: 05/08/17 Time: 22: 12

Sample: 151

Included observations: 51

\begin{tabular}{ccccc}
\hline Variable & Coefficient & Std. Error & t-Statistic & Prob. \\
\hline L & 68668.32 & 24914.37 & 2.756173 & 0.0085 \\
UR & 4924.903 & 2143.480 & 2.297620 & 0.0265 \\
UI & -870.3209 & 326.5016 & -2.665594 & 0.0108 \\
I & -0.219810 & 0.206383 & -1.065058 & 0.2928 \\
E & 9825.886 & 3612.319 & 2.720104 & 0.0094 \\
C & -103097.0 & 38877.00 & -2.651876 & 0.0112 \\
FITTED^2 & 0.000765 & 0.000239 & 3.202543 & 0.0026 \\
FITTED^3 & $-1.36 \mathrm{E}-08$ & $4.08 \mathrm{E}-09$ & -3.329121 & 0.0018 \\
\hline R-squared & 0.380860 & Mean dependent var & $11,664.49$ \\
Adjusted R-squared & 0.280070 & S.D. dependent var & 11115.88 \\
S.E. of regression & 9431.682 & Akaike info criterion & 21.28464 \\
Sum squared resid & $3.83 \mathrm{E}+09$ & Schwarz criterion & 21.58767 \\
Log likelihood & -534.7582 & Hannan-Quinn criter. & 21.40043 \\
F-statistic & 3.778739 & Durbin-Watson stat & 1.471506 \\
Prob (F-statistic) & 0.002809 & & \\
\hline
\end{tabular}


Table 4. Coefficient covariance.

\begin{tabular}{cccccc}
\hline & $\mathrm{L}$ & $\mathrm{UR}$ & $\mathrm{I}$ & $\mathrm{UI}$ & $\mathrm{E}$ \\
\hline $\mathrm{L}$ & 1.000000 & 0.109089 & 0.523987 & 0.402798 & -0.023848 \\
$\mathrm{UR}$ & 0.109089 & 1.000000 & -0.112357 & 0.289754 & -0.301516 \\
$\mathrm{I}$ & 0.523987 & -0.112357 & 1.000000 & 0.310851 & 0.037055 \\
$\mathrm{UI}$ & 0.402798 & 0.289754 & 0.310851 & 1.000000 & 0.121766 \\
$\mathrm{E}$ & -0.023848 & -0.301516 & 0.037055 & 0.121766 & 1.000000 \\
\hline
\end{tabular}

Table 5. Variance Inflation Factor (VIF).

\begin{tabular}{cccc}
\hline $\begin{array}{l}\text { Variance Inflation Factors } \\
\text { Date: 05/09/17 Time: } 11: 23\end{array}$ & & & \\
Sample: 151 & & & \\
Included observations: 51 & & & \\
\hline & Coefficient & Uncentered & Centered \\
\hline Variable & Variance & VIF & VIF \\
\hline L & 13538216 & 2.607003 & 1.533531 \\
UR & 1697828 & 28.24190 & 1.332473 \\
I & 0.041025 & 51.85211 & 1.495678 \\
UI & 798.1428 & 2.063992 & 1.426661 \\
E & 1154743. & 3.342032 & 1.173441 \\
C & $1.99 \mathrm{E}+08$ & 93.13343 & $\mathrm{NA}$ \\
\hline
\end{tabular}

Table 6. B-P test.

\begin{tabular}{|c|c|c|c|c|}
\hline F-statistic & 1.183420 & \multicolumn{2}{|c|}{ Prob. $F(5,45)$} & 0.3323 \\
\hline $\mathrm{Obs}^{*} \mathrm{R}$-squared & 5.926733 & \multicolumn{2}{|c|}{ Prob. Chi-Square(5) } & 0.3134 \\
\hline Scaled explained SS & 15.72309 & \multicolumn{2}{|c|}{ Prob. Chi-Square(5) } & 0.0077 \\
\hline \multicolumn{5}{|l|}{ Test Equation: } \\
\hline \multicolumn{5}{|c|}{ Dependent Variable: RESID^2 } \\
\hline \multicolumn{5}{|l|}{ Method: Least Squares } \\
\hline \multicolumn{5}{|c|}{ Date: 05/09/17 Time: $11: 31$} \\
\hline \multicolumn{5}{|l|}{ Sample: 151} \\
\hline \multicolumn{5}{|l|}{ Included observations: 51} \\
\hline Variable & Coefficient & Std. Error & $\mathrm{t}$-Statistic & Prob. \\
\hline $\mathrm{C}$ & $3.18 \mathrm{E}+08$ & $3.40 \mathrm{E}+08$ & 0.936789 & 0.3539 \\
\hline $\mathrm{L}$ & -31583345 & 88578804 & -0.356556 & 0.7231 \\
\hline UR & -16249215 & 31368654 & -0.518008 & 0.6070 \\
\hline I & -3068.954 & 4876.091 & -0.629388 & 0.5323 \\
\hline UI & 1618139. & 680126.0 & 2.379175 & 0.0217 \\
\hline $\mathrm{E}$ & -12010866 & 25869723 & -0.464283 & 0.6447 \\
\hline R-squared & 0.116210 & \multicolumn{2}{|c|}{ Mean dependent var } & $96,223,601$ \\
\hline Adjusted R-squared & 0.018012 & \multicolumn{2}{|c|}{ S.D. dependent var } & $2.54 \mathrm{E}+08$ \\
\hline S.E. of regression & $2.51 \mathrm{E}+08$ & \multicolumn{2}{|c|}{ Akaike info criterion } & 41.63314 \\
\hline Sum squared resid & $2.84 \mathrm{E}+18$ & \multicolumn{2}{|c|}{ Schwarz criterion } & 41.86041 \\
\hline Log likelihood & -1055.645 & \multicolumn{2}{|c|}{ Hannan-Quinn criter. } & 41.71998 \\
\hline F-statistic & 1.183420 & \multicolumn{2}{|c|}{ Durbin-Watson stat } & 1.484862 \\
\hline Prob (F-statistic) & 0.332324 & & & \\
\hline
\end{tabular}


Table 7. White test.

\begin{tabular}{cccc}
\hline \multicolumn{4}{c}{ Heteroskedasticity Test: White } \\
\hline F-statistic & 1.507544 & Prob. F(19,31) & 0.1510 \\
Obs ${ }^{\star}$ R-squared & 24.49243 & Prob. Chi-Square(19) & 0.1779 \\
Scaled explained SS & 64.97619 & Prob. Chi-Square(19) & 0.0000 \\
\hline
\end{tabular}

Test Equation:

Dependent Variable: RESID^2

Method: Least Squares

Date: 05/09/17 Time: 11: 33

Sample: 151

Included observations: 51

Collinear test regressors dropped from specification

\begin{tabular}{|c|c|c|c|c|}
\hline Variable & Coefficient & Std. Error & t-Statistic & Prob. \\
\hline $\mathrm{C}$ & $-2.53 \mathrm{E}+09$ & $3.16 \mathrm{E}+09$ & -0.799601 & 0.4300 \\
\hline$L^{\wedge} 2$ & $-1.37 \mathrm{E}+09$ & $9.59 \mathrm{E}+08$ & -1.425390 & 0.1640 \\
\hline$L^{\star} U R$ & 25464987 & 87862206 & 0.289829 & 0.7739 \\
\hline$L^{*} I$ & 20918.57 & 15886.21 & 1.316776 & 0.1976 \\
\hline $\mathrm{L}^{*} \mathrm{UI}$ & 6424895 & 4202038 & 1.528995 & 0.1364 \\
\hline$L^{\star} \mathrm{E}$ & $-1.22 \mathrm{E}+08$ & 92463092 & -1.315843 & 0.1979 \\
\hline $\mathrm{UR}^{\wedge} 2$ & -3317806 & 25165675 & -0.131839 & 0.8960 \\
\hline $\mathrm{UR}^{\star} \mathrm{I}$ & -7.099899 & 5607.013 & -0.001266 & 0.9990 \\
\hline $\mathrm{UR}^{\star} \mathrm{UI}$ & -4358946 & 2038714 & -2.138086 & 0.0405 \\
\hline $\mathrm{UR}^{\star} \mathrm{E}$ & 18400010 & 23933054 & 0.768812 & 0.4478 \\
\hline UR & 81993551 & $4.53 \mathrm{E}+08$ & 0.180912 & 0.8576 \\
\hline$I^{\wedge} 2$ & -0.866905 & 0.814500 & -1.064339 & 0.2954 \\
\hline$I^{\star} U I$ & -459.6295 & 207.6165 & -2.213840 & 0.0343 \\
\hline$I^{\star} E$ & 5034.340 & 3584.864 & 1.404332 & 0.1702 \\
\hline I & 88319.76 & 90033.50 & 0.980965 & 0.3342 \\
\hline $\mathrm{UI} \wedge 2$ & 25559.70 & 15663.94 & 1.631754 & 0.1129 \\
\hline $\mathrm{UI}^{\star} \mathrm{E}$ & -1851973 & 1247410 & -1.484655 & 0.1477 \\
\hline UI & 52117631 & 19153717 & 2.721019 & 0.0106 \\
\hline $\mathrm{E}^{\wedge} 2$ & -432060.9 & 14970370 & -0.028861 & 0.9772 \\
\hline $\mathrm{E}$ & $-3.18 \mathrm{E}+08$ & $3.00 \mathrm{E}+08$ & -1.057752 & 0.2983 \\
\hline R-squared & 0.480244 & \multicolumn{2}{|c|}{ Mean dependent var } & $96,223,601$ \\
\hline Adjusted R-squared & 0.161683 & \multicolumn{2}{|c|}{ S.D. dependent var } & $2.54 \mathrm{E}+08$ \\
\hline S.E. of regression & $2.32 \mathrm{E}+08$ & \multicolumn{2}{|c|}{ Akaike info criterion } & 41.65130 \\
\hline Sum squared resid & $1.67 \mathrm{E}+18$ & \multicolumn{2}{|c|}{ Schwarz criterion } & 42.40888 \\
\hline Log likelihood & -1042.108 & \multicolumn{2}{|c|}{ Hannan-Quinn criter. } & 41.94079 \\
\hline F-statistic & 1.507544 & \multicolumn{2}{|c|}{ Durbin-Watson stat } & 1.289353 \\
\hline Prob (F-statistic) & 0.150993 & & & \\
\hline
\end{tabular}


Table 8. Heteroscedasticity-corrected standard error.

Dependent Variable: CRIME

Method: Least Squares

Date: 05/09/17 Time: 13: 56

Sample: 151

Included observations: 51

White heteroskedasticity-consistent standard errors \& covariance

\begin{tabular}{ccccc}
\hline Variable & Coefficient & \multicolumn{1}{l}{ Std. Error } & t-Statistic & Prob. \\
\hline L & -7057.754 & 2826.671 & -2.496843 & 0.0163 \\
UR & -507.8496 & 1044.718 & -0.486112 & 0.6292 \\
I & 0.021916 & 0.149842 & 0.146260 & 0.8844 \\
UI & 88.73031 & 40.15102 & 2.209914 & 0.0322 \\
E & -921.9806 & 815.5975 & -1.130436 & 0.2643 \\
C & 14585.41 & 12281.57 & 1.187585 & 0.2412 \\
\hline R-squared & 0.205683 & Mean dependent var & $11,664.49$ \\
Adjusted R-squared & 0.117426 & S.D. dependent var & $11,115.88$ \\
S.E. of regression & 10442.86 & Akaike info criterion & 21.45536 \\
Sum squared resid & $4.91 \mathrm{E}+09$ & Schwarz criterion & 21.68263 \\
Log likelihood & -541.1116 & Hannan-Quinn criter. & 21.54220 \\
F-statistic & 2.330489 & Durbin-Watson stat & 1.350088 \\
Prob (F-statistic) & 0.057736 & Wald F-statistic & 2.757961 \\
Prob (Wald F-statistic) & 0.029514 & N & \\
\hline
\end{tabular}

RESID08

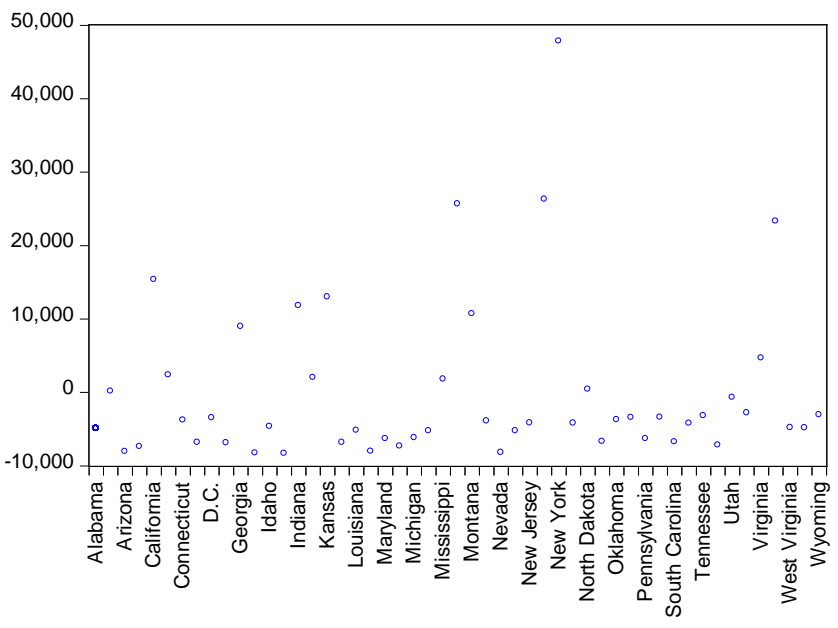

(Unemployment Rate)
RESID09

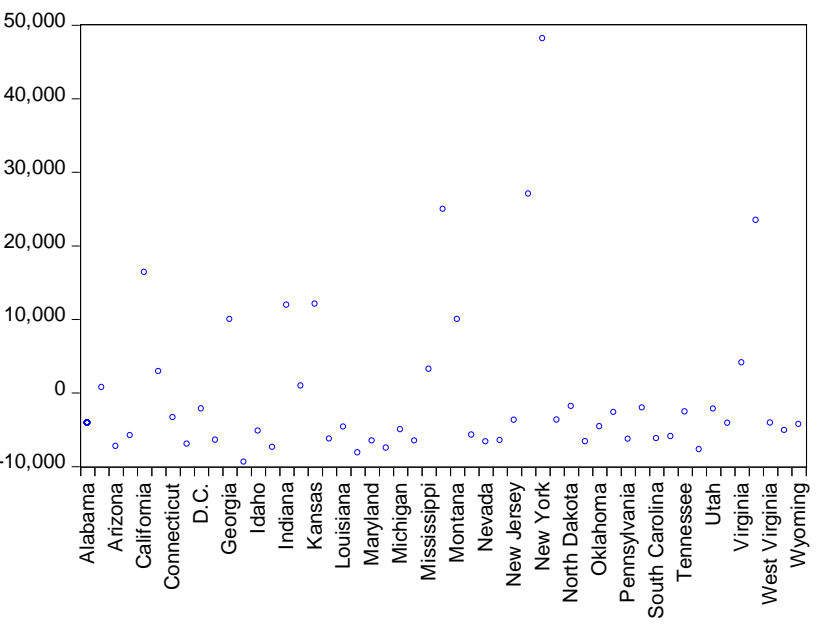

(Median Household Income) 


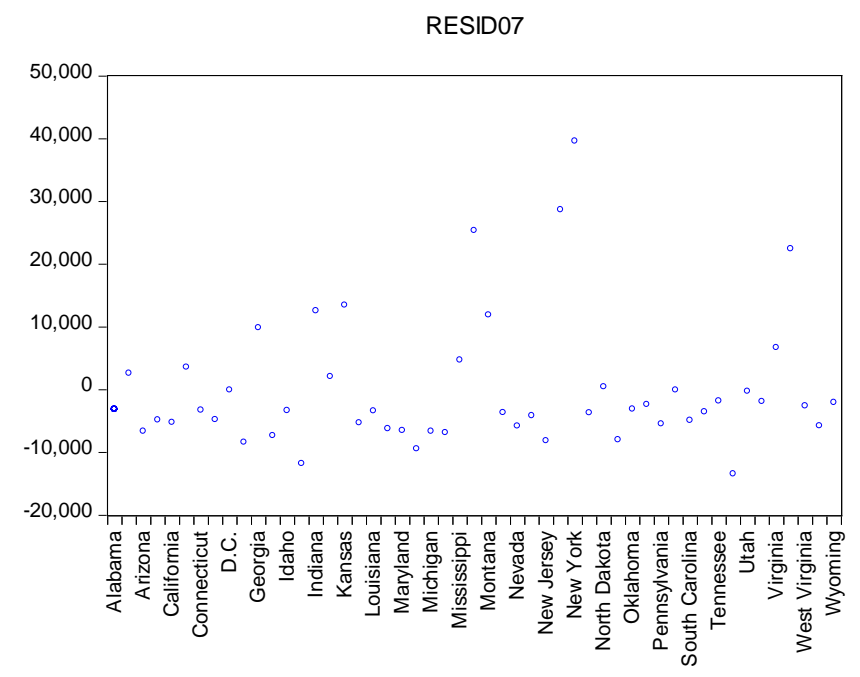

(Unemployment Insurance Policy)

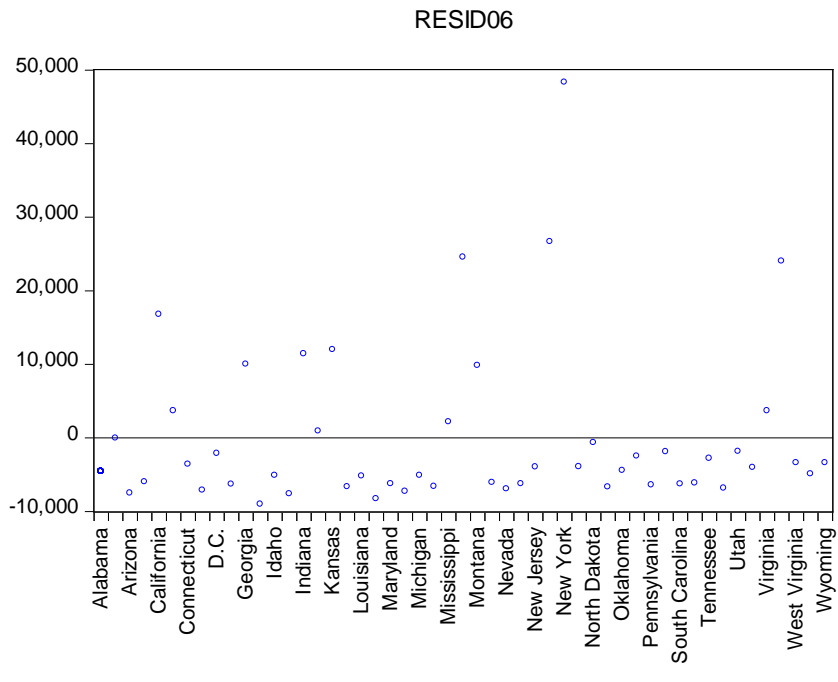

(Education Lever)

Figure 1. Residual graph.

Submit or recommend next manuscript to SCIRP and we will provide best service for you:

Accepting pre-submission inquiries through Email, Facebook, LinkedIn, Twitter, etc. A wide selection of journals (inclusive of 9 subjects, more than 200 journals)

Providing 24-hour high-quality service

User-friendly online submission system

Fair and swift peer-review system

Efficient typesetting and proofreading procedure

Display of the result of downloads and visits, as well as the number of cited articles

Maximum dissemination of your research work

Submit your manuscript at: http://papersubmission.scirp.org/

Or contact jss@scirp.org 